\title{
Regulation Of Charitable Organizations Operating Post September 11, 2001: U. S. Treasury Vs. Charitable Sector
}

Gwendolyn McFadden, (E-mail: mcfaddeg@ncat.edu), North Carolina A \&T State University Jean Wells, (E-mail: jwellsjessup@howard.edu), Howard University

\begin{abstract}
Charitable organizations operating internationally now function in a highly regulated world. After the September 11, 2001 terrorist attack in New York, the U.S. Treasury issued Anti-Terrorist Guidelines to combat and prevent the diversion of charitable contributions to support terrorist activities. The article summarizes the Guidelines and reviews alternative recommendations offered by groups representing various segments of the charitable organization community. The article concludes that the Guidelines should be withdrawn as recommended by the charitable community.
\end{abstract}

\section{INTRODUCTION}

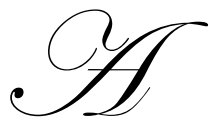

nti-Terrorist Financing Guidelines: Voluntary Best Practices for U.S.-Based Charities (Guidelines) have been recently issued by the United States Department of the Treasury (Treasury). The Treasury perceives an inadequacy in existing rules and regulations that prohibit financial transactions with terrorists and that are intended to prevent the diversion of charitable resources to fund terrorist activities. However, the Guidelines have been met with opposition from the charitable organization community. The consensus among charitable organizations is that the Treasury should withdraw the Guidelines.

This article discusses charitable giving from an income tax perspective, focusing on Internal Revenue Code (I.R.C.) § 501(c)(3) charitable organizations involved in international giving and the efforts of the Treasury to provide guidance to these organizations as a part of the Treasury's overall effort to combat terrorism. The article recounts initiatives and legislation undertaken by the U.S. government, the Treasury and the Internal Revenue Service (I.R.S.), before and after the September 11, 2001 World Trade Center Twin Towers terrorist attack in New York, to combat and prevent the diversion of charitable contributions to support terrorist activities. The article then summarizes the Guidelines issued by the Treasury and reviews alternative recommendations offered by groups representing various segments of the charitable organization community. Lastly, the article concludes that the Treasury should withdraw the Guidelines as recommended by the charitable community. We find that the Guidelines mirror due diligence procedures that would be expected to be effective in any well organized and managed organization. In addition to these general due diligence expectation is the requirement to gather information of the nature that goes beyond existing rules and regulations. Charitable organizations have a right to be concerned, not only about the additional costs but also about unnecessary regulations.

\section{BACKGROUND}

I.R.C. $\S 501(c)(3)$ specifies the tax treatment of organizations that are commonly described as charitable organizations. It provides that organizations organized exclusively for one or more exempt purposes, such as religious, charitable, educational, or scientific, would be exempt from federal income taxes, state income taxes, and certain employment taxes. Organizations seeking tax exemption under I.R.C. § 501(c)(3) must also meet the "common-law standards of charity". The U.S. Supreme Court has interpreted this to mean that the organization must serve a public purpose and not be contrary to "established public policy" (Bob Jones University 1983). Roughly one third of the 3,000,000 tax exempt organizations in the U.S. are classified as I.R.C. § 501(c)(3) (Press Release 2004). 
Concurrent with the benefit of tax exemption to qualifying organizations, the I.R.C provides an incentive to encourage contributions to these organizations. I.R.C. $\S 170$ allows a deduction from federal taxable income for contributions made to I.R.C. $\S 501$ (c)(3) domestic organizations. Although charitable giving transcends national boundaries, the I.R.C. is not as benevolent to donors who make contributions directly to foreign charitable organizations. Deductions for contributions to foreign charities are not allowed by the I.R.C. unless the charity is located in a country that has a treaty with the U.S. which allows for such a deduction. These countries include Canada, Mexico and Israel (I.R.S. Publication 526, 2005).

International charitable giving is not stalled, however, by the deduction limitation on a federal income tax return. The following quote from the Principles of International Charity eloquently depicted the history of international charitable giving and the importance of worldwide partnership to accomplish charitable purposes. "For almost a century, U.S. charitable organizations have engaged in international work. The Rockefeller Foundation, for example, was established in 1913 with a mandate "to promote the well-being of mankind throughout the world," and "launched programs promoting medical education and eradicated, after a 30-year fight, yellow fever throughout the world.... During World War II, charitable organizations helped fill the need for international war relief, and afterwards, they provided humanitarian assistance to survivors. By the 1950s, charitable organizations were engaged in fighting poverty and starvation and promoting health all over the world. When U.S. charitable organizations pursue activities outside the U.S., foreign citizens have the opportunity to have personal contact with U.S. citizens."

Indeed, historically, charities have responded to disasters, both natural and man-made, by raising and distributing billions of dollars to disaster victims and survivors. For example, more recently, charitable organizations raised countless dollars to aid thousands of victims of the tsunami that devastated southern Asia in 2004. After the September 11, 2001 terrorist attack on the U.S., charities raised and dispensed over $\$ 2.7$ billion of aid to victims. Similarly, in 2005 , charitable organizations raised over $\$ 4$ billion to assist victims of Hurricane Katrina which devastated New Orleans, and portions of Mississippi and Alabama.

Whether organized domestically or in foreign countries, charitable work fills critical gaps in the global socioeconomic infrastructure (Principles 2005). Many charities operate independently, but more work is accomplished through partnership between domestic and international organizations. By partnership, we mean the contribution of financial resources or grantmaking primarily. Grantmaking is considered "an integral means of building partners overseas and contributing to sustainable development, and is often essential in order to ensure effective relief and development programming" notes InterAction, the largest alliance of U.S. international development and humanitarian nongovernmental organizations (Public Comment 2003).

International partnership, however, comes at a cost. After the attack on the U.S., the management and governance of charitable organizations, particularly those with international ties, became the subject of heightened scrutiny (Panel 2006)(Stokeld 2004). Of concern then and now is the diversion of resources from charitable organizations operating in good faith to organizations and efforts that support terrorist groups and their activities. In 2001, the I.R.S., an agency of the Treasury, sought comments from the public on how it might clarify the existing rules related to grant-making and other international activities. Of particular interest were comments on "how new guidance might reduce the possibility of diversion of assets for non-charitable purposes while preserving the important role of charitable organizations world-wide.” The I.R.S. explained that the September 11, 2001 attack created a need to take comprehensive measures to prevent terrorism. This measure was needed because specific situations were disclosed involving the use of charitable organizations to provide significant funding to finance terrorist activities. The funds were traced to U.S. based charitable organizations as well as from foreign organizations supported by U.S. contributors (I.R.S. Ann. 2003-29). Were not laws and regulations already in place to prevent such an occurrence? 


\section{REGULATORY OVERSIGHT BEFORE AND AFTER SEPTEMBER 11, 2001}

\section{Before September 11, 2001}

Before the September 11, 2001 terrorist attack on the U.S., several laws and executive orders were in place aimed at curtailing terrorism. These are summarized below.

United States Code (U.S.C.) § 2339A and § 2339B

In the 1990s, Congress determined that international terrorism was a serious and deadly problem that threatened the vital interests of the U.S. To minimize this threat, in 1994, Congress enacted legislation to address these concerns that imposed both criminal and civil penalties on institutions that knowingly provided material support or resources to a foreign terrorist organization. Material support and resources include any "property, or service, including currency or monetary instruments of financial securities" (18 U.S.C. § 2339A). This legislation was enacted because Congress found that some foreign terrorist organizations were raising significant funds within the United States to be used for terrorist purposes.

To violate the statute and be subject to the penalty, the institution must have knowledge that the organization is a foreign terrorist organization (FTO), and that the organization has engaged or engages in terrorist activity or terrorism. When the institution becomes aware that they are in possession of funds in which an FTO has an interest, the institution must maintain control over the funds, and report the existence of the funds to the Secretary of the Treasury (18 U.S.C. $\S 2339 \mathrm{~B})$. Whether an organization is an FTO or not is a fact that must be proven by the government. The government bears the burden of proving beyond a reasonable doubt that the institution knew that the organization was an FTO or was designated as such and that the institution knew that it was furnishing material support to the organization. Specific knowledge and intent is required for conviction (United States v. Al-Arian 2004); therefore, charitable organizations and other institutions operating in good faith would normally not be affected by this statute.

\section{Executive Orders}

President William Clinton issued two executive orders that addressed the contribution of funds to persons and entities that pose a threat to the security of the U.S. Executive Order 12947 was signed on January 23, 1995. The order specifically prohibited U.S. persons or entities from making or receiving any "contributions of funds, goods, or services to or for the benefit of" twelve specifically identified FTOs and other organizations identified by collaborative efforts of the Secretary of State, Secretary of the Treasury, and the Attorney General to have posed a threat to the Middle East peace initiatives. It also blocked transactions including the contributions of funds to finance violent acts against the U.S., thereby freezing these assets in the U.S. This order was amended in 1998 to include Osama bin Laden and several additional terrorist organizations. President Clinton, who was instrumental in brokering the historic Middle East peace accord between Israel and Palestine, also signed Executive Order 13129 on July 4, 1999, which addressed similar threats posed by the Taliban.

\section{Anti-Terrorism and Effective Death Penalty Act of 1996}

Congress passed the Anti-Terrorism and Effective Death Penalty Act of 1996 (Anti-Terrorism Act) primarily in response to the World Trade Center and Oklahoma City bombings in 1993 and 1995, respectively. The AntiTerrorism Act contains a prohibition on international terrorist fundraising designed to prevent U.S. organizations and individuals from providing material support or resources to foreign organizations that engage in terrorist activities. The Anti-Terrorism Act also authorizes the Secretary of the Treasury to freeze the assets of FTOs. Embedded in the Anti-Terrorism Act are procedures to prevent fundraising in the U.S. to support terrorist organizations abroad. 


\section{I.R.S. Rulings}

Several I.R.S. rulings were in place prior to September 11, 2001, but none specifically addressed the issue of terrorism. They addressed the question of whether or not the organization would be precluded from qualifying as a tax exempt organization if some or all activities were conducted outside the U.S. (Rev. Rul. 71-460), if the organization distributed funds to organizations that were not \$501(c)(3) organizations (Rev. Rul. 68-489), and if the organization makes grants to individuals (Rev. Rul. 56-304). Other revenue rulings addressed the question of whether or not gifts donated to domestic charities and later transferred to foreign charities were deductible. (Rev. Rul. 63-252 and Rev. Rul. 66-79).

\section{After September 11, 2001}

The U.S. government's reaction to the September 11, 2001 terrorist attack on the U.S. was swift and began a period of intense reaction by the federal government.

\section{Executive Order 13244}

Less than two weeks after the attack, on September 23, 2001, President George W. Bush issued Executive Order 13244. Similar to Executive Orders issued by President Clinton, the Order blocked transactions involving "Specifically Designated Nationals" (SDN) that posed a risk of committing terrorist acts against the U.S. and also prohibited contributions supporting their efforts. Twenty-seven individuals and entities were listed in the Executive Order. As of January 2007, hundreds of additional SDNs have been identified.

\section{USA Patriot Act}

Also shortly after September 11, 2001, Congress enacted the USA Patriot Act to enhance domestic security against terrorism, enhance surveillance procedures, address international money laundering activities, strengthen existing statutes and regulations against terrorism such as 18 U.S.C. $§ 2339 \mathrm{~A} \& \S 2339 \mathrm{~B}$, and expand presidential powers. The Act raises privacy issues and has been criticized by the American Civil Liberties Union. Although this Act did not directly target charitable organizations, because of its breadth, it affects anyone who provides financial support to terrorist efforts, including the activities of charitable organizations.

\section{U.S.C. $\$ 2339 C$ - Prohibitions Against the Financing of Terrorism}

In 2002, Congress enacted 18 U.S.C. $\S 2339$ C, to address organizations that may be below the radar of $\S$ 2339A \& $\S 2339 \mathrm{~B}$. This section criminalizes the unlawful and willful provision (via gift, donation or transmittal) or collection (via raising and receipt) of funds with the intention that the funds will be used to carry out harmful acts of terrorism. The Act does not require that the funds were actually used to carry out a predicate act, only that the intent to carry out the act is present.

\section{I.R.C. Section 501(p) - Suspension of Tax-exempt Status of Terrorist Organizations}

This new tax provision, effective November 11, 2003, was enacted to respond to the war on terrorism by specifically addressing the exempt status of charitable organizations. Pursuant to I.R.C. § 501(p), the tax exempt status of any organization, identified as a terrorist organization, will be suspended. During the period of suspension, donors are not allowed a deduction for contributions made to these organizations. The suspension will end when all designations and identifications are rescinded pursuant either to the law or to the Executive Order under which the designation or suspension was made.

Unlike most administrative or judicial determinations, an organization cannot challenge the suspension. This appears to be a harsh rule, particularly since mistakes are likely to occur. Considering this possibility, the provision provides that if an organization is designated as terrorist by mistake and the exemption is suspended, overpayment of income taxes as a result of the suspension will be refunded to the organization. The statute of limitations or other 
operations of law will not preclude a refund if the organization makes its claim within the prescribed period. Each time an organization is suspended, the I.R.S. updates the list of tax-exempt charitable organizations and identifies those organizations which have been suspended. Surprisingly, only eight organizations have had their tax exempt status suspended under this section. These suspensions occurred in 2003 and 2004.

Table 1: Suspension of Tax-Exempt Organizations Identified as Terrorist Organizations

\begin{tabular}{|l|}
\hline \multicolumn{1}{|c|}{ Organization Name/Location } \\
\hline Al Haramain Islamic Foundation, Inc., Ashland, Oregon \\
\hline American Friends of United Yishuv Movement, Brooklyn, New York \\
\hline Benevolence International Foundation, Inc., Palos Hills, Illinois \\
\hline Global Relief Foundation, Inc., Bridgeview, Illinois \\
\hline Holy Land Foundation for Relief and Development, Richardson, Texas \\
\hline Islamic African Relief Agency - USA, a/k/a Islamic American Relief Agency - USA, Columbia, Missouri \\
\hline Kahane Net, Brooklyn, New York \\
\hline Rabbi Meir Kahana Memorial Fund, Cedarhurst, New York \\
\hline $\begin{array}{l}\text { Source: I.R.S. web site available at http://www.I.R.S..gov/charities/charitable/article/0,id=141459,00.html (last visited January } \\
\text { 23, 2007). }\end{array}$ \\
\hline
\end{tabular}

\section{ANTI-TERRORIST FINANCING GUIDELINES: VOLUNTARY BEST PRACTICES FOR U.S. BASED CHARITIES}

The Treasury publicly voiced concern that existing tax guidance governing international grantmaking and international activities of domestic charities did not prevent the diversion of charitable assets to terrorist activity. In 2002, it issued "Anti-Terrorist Financing Guidelines: Voluntary Best Practices for U.S. Based Charities". The Guidelines were conceived as a "direct response to requests from the sector for policies and practices to protect against potential terrorist abuse and assist in compliance with new terrorist financing authorities, including Executive Order 13224." These Guidelines identified ways to reduce the risk that charitable funds would be diverted to terrorist purposes. The Treasury revised the Guidelines in 2005 and again in October 2006 (Treasury Department 2006). The 2006 Guidelines are organized into six sections and are summarized below.

Section 1 - The introduction section establishes the purpose of the Guidelines and their link to Executive Order 13224. The Guidelines state that they are intended to assist charities in understanding and facilitating compliance with existing laws related to combating terrorist financing. The Guidelines are designed to enhance public awareness of the types of "practices that may be adopted to reduce the risk of terrorist financing and abuse". The Guidelines also recommend that the charitable organization maintain an effective system of internal control designed to reduce the risk of resources being diverted to finance terrorist activities. The Guidelines clearly indicates that it is not a mandatory set of guidelines, that charities may adopt it on a voluntary basis, that it is not exhaustive nor comprehensive and cautions that it should not be substituted for existing laws, regulations or organizational due diligence procedures.

Section 2 - Fundamental Principles of Good Charitable Practice. The Guidelines specifically state that the charities are not a part of the U.S. government, and that they must comply with U.S. laws. They include a list of existing laws and regulations promulgated to address terrorism. The Guidelines contain links to government websites to assist in locating relevant regulatory and statutory authority. Finally, the Guidelines encourage charities to adopt practices that insure accountability of assets and to exercise due diligence by individuals at all levels of the organization.

Section 3 - Governance Accountability and Transparency. The Guidelines recommend that the organization operate in accordance with its governing document as well as comply with existing laws and regulations. The Guidelines also recommend that the organization provide independent oversight of its operations by creating a governing board vested with specific roles of accountability. Nevertheless, while recognizing the privacy of rights of 
individuals, the Guidelines recommend that personal information about the governing board members and key personnel be maintained by the organization and that these records be made available to law enforcement.

Section 4 - Financial Accountability and Transparency. The Guidelines recommend that the organization maintain a budget, have one individual serve as financial officer, be audited by a certified public accounting firm if its gross income exceeds $\$ 250,000$, and state the purpose of solicited funds. Documentation should indicate how and where the donations are going to be expended, disclose when funds are not used for intended purpose, and account for the receipt and disbursement of funds in accordance with generally accepted accounting practices. Finally, the charitable organization should make available for public inspection a list of entities that receive resources from the charity, an annual report and the most recent audit report.

Section 5 - Programmatic Verification. This section focuses on accountability of and fiscal responsibility for resources, concentrating on grantmaking. The organization should ensure that the grantee is capable of accomplishing the purpose of the grant and be able to protect the funds from diversion to terrorist activity. The organization should also continuously monitor the grantee activity and terminate relationships when appropriate.

Section 6 - Anti-Terrorist Financing Best Practices. This section contains three recommendations on grantmaking. The first recommendation calls for a collection of basic information about the grantee, its key employees and individuals or entities to which the grantee provides resources. Information includes name, historical information, annual reports, sources of income and place of jurisdiction including postal, email and URL addresses. The second recommendation involves a vetting of grantees to determine whether they are suspected of terrorist activity. The third recommendation is that the charitable organizations conduct basic vetting of its own employees and governing board to determine if they are suspected of terrorist activity. The Guidelines contain various websites that charities may use to conduct research.

\section{RESPONSES TO THE GUIDELINES}

\section{Principles Of International Charity}

In March 2005, a group of influential charitable organizations and advisors published the Principles of International Charity (Principles) in response to and as an alternative to the 2002 Guidelines. These Principles "describes the fundamental principles that guide the international charitable work of experienced U.S. organizations" and "reflect a range of due diligence procedures that have proven effective in minimizing the risk of diversion of charitable assets and mitigating the real security threat facing many of those delivering charitable assistance without discouraging international charitable activities by the U.S. organizations." The Principles reflect eight key concepts germane to good governance and due diligence.

1. A charitable organization must be committed to its mission and exclusively pursue the charitable purpose for which it was organized whether domestically or internationally focused.

2. A charitable organization must comply with both U.S. laws applicable to charities and relevant laws of the foreign jurisdiction, while maintaining its independence from the government. These laws include the oversight responsibilities required under tax laws as well as other relevant anti-terrorist laws including Executive Orders, the USA Patriot Act and 18 USC $\$ 2339$.

3. In addition to complying with laws and regulations, a charitable organization should adopt practices that it believes will provide confidence that all its assets are used exclusively for charitable purposes.

4. The governing board is responsible for establishing a culture of compliance with regulations and laws, and adopting and implementing the principles and practices of the organization.

5. The organization must be committed to the charitable use of its resources at every level.

6. When supplying charitable resources, the organization should ensure that the grantee has the ability to accomplish the charitable purpose as well as protect the diversion of resources for non-charitable purposes. The organization and grantee should execute a signed written agreement. The organization should continuously monitor the grantee and activities funded under the grant. Finally, the organization should correct any misuse of resources by the recipient. 
7. A charitable organization should exercise fiscal responsibility which involves taking appropriate measures to reduce the risk that assets will be misused. Measures include having sufficient financial controls in place to track funds between the provider and recipient.

8. The organization must safeguard its relationship with the communities it serves in order to deliver effective programs given the dangerous areas of the world in which they serve. This involves acceptance of the independence of the charity.

The Treasury issued revised Guidelines in November 2005 and again in 2006. The Treasury also solicited public comments. The comments and recommendations from two prominent groups regarding the revised versions of the Guidelines are summarized below.

\section{American Bar Association}

In April 2006, the Tax Section of the American Bar Association (ABA) recommended that the Guidelines be withdrawn and replaced with the Principles (American Bar Association 2006). Alternatively, the ABA offered the following comments.

1. The ABA commented that the Guidelines contained provisions suggesting that charitable organizations are agents of the government. There was a fear that the charitable organizations' workers might be perceived to be government agents which could compromise the safety of humanitarian workers. The ABA also noted that the Guidelines tended to blur the critical separation between the U.S. government and the charitable sector which would undermine the trust between U.S. charities and foreign recipients. The Treasury completely agreed with this observation and clarified this position in the 2006 revision with a discussion regarding the independence of charitable organizations.

2. The ABA stated that the Guidelines were unduly burdensome because they required the collection of more information on more individuals and organizations than was previously required. There was a concern that the information collection went well beyond the capacity of most charitable organizations. The Treasury realized that the information gathering process it proposed was expansive but nevertheless reiterated that this level of information gathering is essential to good governance. The Guidelines encouraged the charities to undertake their own risk assessment based on their own needs. The Guidelines also distinguished between information requested from immediate grantees and downstream grantees, asserting that more information was needed about the immediate grantees, and less information about the downstream grantees.

3. There was concern that the Guidelines appeared to address more than their stated purposes and created a duplication of efforts. The ABA indicated that the Guidelines addressed issues already covered by state or federal laws or by highly developed practices widely accepted in the charitable sector. Another critical concern was that the Guidelines could evolve into de facto legal requirements through incorporation into other federal programs, despite the inclusion of the word voluntary in the title. The Treasury disagreed with this comment. The Treasury pointed out that the 2006 revision of the Guidelines specifically state that nonadherence does not constitute a violation of existing laws.

4. Specific comments were directed to the Title of the Guidelines. The ABA criticized the title noting "it is not accurate to present the Guidelines as a compilation of the sector's best practices particularly given the diversity of the charitable sector". The ABA recommended the title be changed to "Suggestions for Complying with Anti-Terrorist Financing Laws". In response to this comment, the Treasury indicated that the title did not misrepresent the purpose or intent of the Guidelines. A "wide spectrum of existing due diligence best practices employed by the sector" were developed and incorporated into the Guidelines to specifically address efforts to combat terrorist financing, the Treasury noted.

5. The ABA expressed a belief that the Guidelines make broad and sweeping statements regarding the extent of diversion of charitable assets to terrorist purposes, including a misrepresentation of the prevalence of terrorist abuse of U.S. charities. The ABA requested the Treasury to disclose specific data regarding diversion, such as the number of individuals and organizations that have been designated terrorist entities or supporters as well as the amount of money frozen worldwide. The ABA asserted that specific data would not undermine donor confidence but would educate charitable organizations about the threat and realities of terrorist use of charitable assets. In response, the Treasury included an "Annex" with the 2006 Guidelines that provided 
some indication of the number of entities and individuals who have been designated as terrorist. The Treasury cites its website as a source of updated information that will assist charitable organizations as well as donors in identifying organizations associated with terrorist activity.

\section{Council On Foundations}

The above comments were consistent with those offered by the Council on Foundations (Council), an organization representing a broad group of U.S. charitable organizations and legal advisors, in response to the revised 2005 Guidelines. Less than two months after the release of the revised 2006 Guidelines in October, the Council responded. Once again, it urged that these Guidelines be withdrawn and that the Principles be endorsed. It appears that the Guidelines were still considered inadequate, notwithstanding the modifications made to the 2005 draft. Realizing that the Guidelines might not be withdrawn, the Council offered the following alternatives, which practically mirrored recommendations offered by the ABA several months earlier (Gunderson 2006).

1. The Council determined that the Guidelines significantly exaggerate the extent to which U.S. charities have served as a source of terrorist funding. The Council asked the Treasury to provide data on the prevalence of terrorist abuse of U.S. charities. The Annex attached to the Guidelines did not address the concerns of the Council because "it does not distinguish between domestic and foreign charities and failed to prove an accurate picture of the dollars involved in terrorist abuse of charities." The Council believes that the risk is overstated.

2. The Council determined that onerous information collection and reporting requirements are still present that do little to protect the charities from terrorist abuse. Troubling new provisions included those that advise charities not to enter into relationships where "any terrorist-related suspicion exists" and that the charities "report board member or key employees to [Office of Foreign Assets Control] if they find any suspicious activity relating to terrorism". These terms, the Council believes are vague and undefined and that reporting is inappropriate in the absence of solid evidence of terrorist related activity.

3. The Council noted that the I.R.S. does not go far enough to ensure that the Guidelines remain voluntary. The Council cited instances in which the I.R.S. asked if the organizations complied with the Guidelines in the context of tax audits and exemption applications.

4. The Council noted that since much of the work performed by U.S. charities around the world is designed to address conditions that breed terrorism, charities may not have the resources to fund the cost of complying with the Guidelines. The Council also expressed concern that donors will be deterred from funding the work of charities because Treasury has overstated the risk of diversion of assets from legitimate charities.

\section{Other Comments}

The Treasury received a total of nine comments on the revised 2006 Guidelines, including the comment from the Council (Treasury Department 2006). According to the Treasury, some commentators recommended that the 2006 revised Guidelines be withdrawn based on the "perception that the Guidelines are potentially harmful to the charitable sector given the existing regulations governing the operations of charities." Grantmakers Without Borders, a philanthropic group of organizations dedicated to providing humanitarian support to the Global South, indicated that the Guidelines were unrealistic and counterproductive (Grantmakers Without Borders 2006). The group also stated that the Guidelines will have chilling effect on valuable work. In addition, the group believes that the Treasury has provided no "real, non-anecdotal evidence" that charitable funds are unintentionally being diverted for terrorist purposes. 


\section{DISCUSSION}

Although opposed by many prominent charitable organizations, the Treasury states that it will not withdraw the Guidelines. It justifies its position by pointing to the voluntary nature of the Guidelines and the benefits of the proactive approaches initiated by some organizations as a result of the dialogue between the charitable sector and the Treasury. A variety of reasons were articulated including their belief that the adoption of the Guidelines by charities with a high degree of vulnerability will not adversely affect the "financial health", or "obstruct the day-to-day operations" of the charitable sector. The Treasury believes that effective counter-terrorist measures build upon preexisting controls and other safeguards and that the evolution of the Guidelines has fostered a stronger ongoing dialogue with the charitable sector.

The most recent version is the Treasury's third attempt at developing guidelines to accomplish its stated goal, which is to assist charities in understanding and facilitating compliance with existing laws as these laws relate to terrorism. Each time these rules have met with resistance by the sector that it is designed to help. For a variety of reasons, the charitable sector does not endorse these Guidelines. Because the Treasury's Guidelines do not carry the force and effect of law, and compliance is voluntary, can a charity choose to simply ignore them?

The answer is probably no. The concern voiced by the ABA referred to the probability that the Guidelines would be perceived as de facto law. There is evidence to support this assertion. The charitable sector observed that the Guidelines have been incorporated into the 2006 Combined Federal Campaign (CFC) and are also included in the commentary accompanying the CFC regulations. The CFC facilitates fundraising from federal employees on behalf of charitable organizations. They further observed that the Guidelines have been the subject of inquiry during tax audits. A recent tax article published by the American Institute of Certified Public Accountants (Reilly 2006) identified the Guidelines as one factor to consider when the organization re-examines its cross-border grants. The mere fact that the Guidelines were issued by the Treasury and include a reference to "best practices" to avoid abuse by terrorist organizations substantially increases the degree of compliance expected from the organization.

The need for strong governance over charitable funds that could be diverted for terrorist purposes is clear. Indeed, notwithstanding the unique aspects of each document, there exists a common thread that runs through the Guidelines and the Principles on which good governance could be built. For example, both documents clearly identify and strongly articulate an appreciation for the charitable organizations to remain independent from the government. Also expressed, is a requirement that charitable organizations follow existing rules and regulations. Both documents address the issue of financial accountability, noting that funds should be traceable and operations monitored. Finally, both documents include a statement that the charitable organizations should ensure that the grantee/recipient be able to accomplish the desired charitable purpose.

Each governing document presents the due diligence practices in a unique manner. The Principles mix the requirements of due diligence with an overarching tone of personal and social awareness. The Principles emphasize the need for commitment to the use of funds for charitable purposes. They hold that the organization should establish a culture of compliance, and they seem to place the monitoring of relationships on the same level as the monitoring of resources. These attributes suggests a real human element to the governance process.

Conversely, the Treasury combines its due diligence practices with a call for detailed and personal information, and very specific record-keeping requirements, some of which must meet the high standards of generally accepted accounting principles. The Guidelines also call upon the charitable organization to take appropriate steps to ensure that its funds are not distributed to terrorists or others to be used for terrorist purposes. To this end, periodic audits should be conducted. The Guidelines also require collection of specific information about the grantee, vetting of grantees and the organization's key employees, and reporting of "any suspicious activity relating to terrorism." 


\section{CONCLUSION}

Charitable organizations find themselves operating in a more highly regulated world since the September 11, 2001 terrorist attack on the U.S. Of concern to the government is the possible abuse of charitable resources by terrorists. Specifically, the Treasury, its agent, the I.R.S. and the charitable community are concerned that charitable funds may be diverted to finance terrorist activities. To address this issue, the Treasury issued and revised, on three occasions, Guidelines containing due diligence recommendations and other information gathering procedures. Although the revisions incorporated comments from the charitable community, the Guidelines have been rejected by many influential organizations within the charitable sector. Instead, the charitable community would prefer to adopt the Principles, which it believes provides a more practical approach to the issue.

Without debate, both the Treasury and the charitable community agree that guidance is necessary. Although offered as a voluntary measure, the Guidelines carry with them a sense of regulatory authority, an expectation of compliance, and a degree of outside governance that contributes to heightened scrutiny of the charitable sector post September 11, 2001.

Charitable organizations, however, find that the Guidelines are unduly burdensome, a duplication of due diligence efforts, and contrary to the Treasury's intent, they impede charitable efforts. For these reasons the Treasury Guidelines should be withdrawn in favor of the Principles of International Charity pending the development of more acceptable standards.

\section{REFERENCES}

1. American Bar Association Section of Taxation and Criminal Justice, ABA Members Comment on Antiterrorist Financing Guidelines, The Exempt Organization Tax Review, May 2006.

2. Anti-Terrorism and Effective Death Penalty Act of 1996, P.L. 104-132 (1996).

3. Bob Jones University v. United States, 461 U.S. 574 (1983).

4. $\quad 18$ U.S.C. $\$ 2339$ A (1994).

5. $\quad 18$ U.S.C. $\S 2339$ B (1996).

6. $\quad 18$ U.S.C. $\$ 2339$ C (2002).

7. $\quad$ Exec. Order 12947, 60 Fed. Reg. 5079 (Jan. 25, 1995).

8. $\quad$ Exec. Order13129, 64 Fed. Reg. 36750 (July 7, 1999).

9. $\quad$ Exec. Order 13224, 66 Fed. Reg. 49,079 (Sept. 25, 2001).

10. Grantmakers Without Borders (Letter to The Honorable Henry M. Paulson, Jr., Secretary of the Treasury) December 22, 2006, available at http://www.internationaldonors.org/news/gwob_letter_122206.pdf (last visited January 23, 2007).

11. Gunderson, Steve, Charities Criticize Treasury's Updated Anti-Terrorist-Financing Guidelines, 2006 TNT 243-12.

12. I.R.S. Ann. 2003-29, 2003-29 I.R.B. 928.

13. I.R.S. Pub. 526, Charitable Contributions, (December 2005).

14. I.R.C. $\S 170(1986)$.

15. I.R.C. $\$ 501(\mathrm{c})(3)(1986)$.

16. I.R.C. $\$ 501(\mathrm{p})(2004)$.

17. Panel on the Nonprofit Sector (Convened by Independent Sector), Strengthening Transparency Governance Accountability of Charitable Organizations, a supplement to the final report to Congress and the Nonprofit Sector, April 2006 available at http://www.nonprofitpanel.org/supplement/Panel_Supplement_Final.pdf (last visited January 23, 2007).

18. Press Release, IR 2004-81, Internal Revenue Service, IRS Commissioner Testimony: Charitable Giving Problems and Best Practices (Written statement of Mark W. Everson, Commissioner of IRS), June 22, 2004 available at http://www.irs.gov/newsroom/article/0,id=124186,00.html (last visited January 23, 2007).

19. Principles of International Charity, International Programs Council on Foundations, March 2005, available at http://www.cof.org/files/Documents/International_Programs/Principles_Final.pdf (last visited January 23, 2007). 
20. Public Comment on "International Grantmaking and International Activities by Domestic 501(c)(3) Organizations" Submitted Jointly by Interaction and Independent Sector, July 18, 2003, available at http://www.gwob.net/news/gwob_letter_122206.pdf (last visited January 23, 2007).

21. Reilly, Kevin, Beware U.S. Tax Rules on Grants to Foreign Organizations, The Tax Advisor, (November 2006).

22. Rev. Rul. 56-304, 1956-2 C.B. 306.

23. Rev. Rul. 63-252, 1963-2 C.B. 101.

24. Rev. Rul. 66-79, 1966-1 C.B. 48.

25. Rev. Rul. 68-489, 1968-2 C.B. 210.

26. Rev. Rul. 71-460, 1971-2 C.B. 231.

27. Specifically Designated Nationals, http://treas.gov/offices/enforcement/ofac/sdn/t11sdn.pdf, (last visited January 18, 2007).

28. Stokeld, Fred, EO Conference Focuses on Charity Abuses, 43 Exempt Org. Tax Rev. 15 (2004).

29. Toscher, Steven, Tax Tips: IRS Scrutiny of Tax-Exempt Organizations, 28 Lost Angeles Lawyer 18, October 2005.

30. Treasury Department, Anti-Terrorist Financing Guidelines: Voluntary Best Practices for U.S.-Based Charities, 71 Fed. Reg. 63838 (Oct. 31, 2006), also available at http://treas.gov/offices/enforcement/keyissues/protecting/ (last visited January 23, 2007).

31. United States v. Al-Arian, 308 F Supp 2d 1322, (2004)

32. USA Patriot Act, P.L. 107-56 (2001).

\section{NOTES}




\section{NOTES}

